\title{
Formativ feedback styrker skriftlighed hos studerende fra It og Sundhed
}

Katja Årosin Laursen, akademisk sprogkonsulent, Center for Internationalisering og Parallelsproglighed, Københavns Universitet.

Lars Kayser, lektor, Institut for Folkesundhedsvidenskab, Københavns Universitet.

Mads Kamper-Jørgensen, lektor, Institut for Folkesundhedsvidenskab, Københavns Universitet.

\section{Faglig artikel (bedømt af redaktionen)}

I denne artikel proesenterer vi erfaringerne fra et projekt, der har til formål at styrke de studerendes danske, akademiske skrivefordigheder på uddannelsen It og Sundhed på Københavns Universitet. Projektet bygger på antagelserne, at faglighed og formidlingskompetencer er toet forbundet, og at sproglig bevidsthed inden for fagets kontekst er et faelles ansvar mellem underviser og studerende. Projektet er knyttet til bachelorkurset $i$ Epidemiologiske metoder, og det er udviklet i samarbejde mellem kursuslederen og en sprogkonsulent i løbet af forårssemestrene 2014 og 2015. Gennem skriftlige afleveringer og formativ feedback på disse har de studerende haft mulighed for at arbejde med deres skriftlige formidling som forberedelse til den skriftlige eksamen i kurset og som styrkelse af deres akademiske skrivefardigheder generelt. I artiklen beskriver vi baggrunden for projektet og erfaringerne med at udvikle og gennemføre det. Derudover diskuterer vi projektets udbytte samt udfordringerne med at saette eksplicit fokus på fagets sproglige aspekt. På baggrund af de studerendes evaluering og eksamensresultater konkluderer vi, at projektet har medvirket til at styrke deres akademiske skriftlighed.

\section{Indledning}

Mange eksamener på universitetet er skriftlige, men det er ikke altid, at de studerende får mulighed for at udvikle deres skriftlige færdigheder og få feedback på deres egne tekster, inden de skal til skriftlig eksamen. Som studerende kan det være vanskeligt at finde ud af, hvordan man griber en skriftlig universitetsopgave an. Hvordan skal de bundne opgaveformuleringer forstås? Hvor omfattende skal ens besvarelse være? Hvordan skriver man en universitetsopgave, der lever op til de akademiske krav om klar og præcis formidling af den faglige viden? Mange af svarene på disse spørgsmål forbliver desværre ofte tavs viden hos underviserne, fordi der ikke er midler eller tid til at udvikle skriftligheden som en del af de studerendes kompetencer i løbet af kurserne på universitetet. På uddannelsen It og Sundhed på Københavns Universitet (KU) har vi forsøgt at ændre denne situation gennem et projekt, der fokuserer eksplicit på at styrke de studerendes skriftlighed i kurset Epide- 
miologiske metoder på 2. semester. Det har vi gjort ved at indføre to skriftlige afleveringsopgaver i løbet af kurset, som de studerende får feedback på. Feedbacken består dels af kommentarer fra kursets fagunderviser og en sprogkonsulent og dels af peerfeedback. Vores intention har været at støtte de studerendes læring i et iterativt læringsforløb ved at evaluere deres skriftlige formidling vha. formativ feedback. Ifølge Black \& Wiliam (1998, s. 7-8) omfatter formative assessment:

"all those activities undertaken by teachers, and/or by their students, which provide information to be used as feedback to modify the teaching and learning activities in which they are engaged."

Lige som Black \& Wiliam betragter vi formativ evaluering som en samlebetegnelse for alle de aktiviteter, som kan sige noget om de studerendes læring, og som kan bruges til at regulere undervisningen og læringsaktiviteterne for at fremme de studerendes læring. Det formative indebærer, at feedbacken guider den studerende mod konkrete handlemuligheder, som vedkommende kan arbejde med fremadrettet.

Projektet er udviklet i tæt samarbejde mellem fagunderviseren og sprogkonsulenten, og tværfagligheden er med til at sikre, at de studerende får så grundig og eksplicit en feedback som muligt. Artiklen kan anvendes som inspiration til, hvordan man som underviser kan integrere skriftlige opgaver og formativ feedback i et allerede eksisterende kursus for at styrke de studerendes akademiske skriftlighed.

\section{Baggrund}

For at imødekomme et stigende behov for innovation og velfærdsteknologi i sundhedssektoren har KU i samarbejde med Danmarks Tekniske Universitet siden 2008 udbudt en 5-årig universitetsuddannelse i it og sundhed. I modsætning til de øvrige sundhedsvidenskabelige bacheloruddannelser på KU har der med undtagelse af 2014 ikke været nogen adgangskvotient for optagelse på It og Sundhed, og alle ansøgere er derfor blevet optaget. På tværs af uddannelsens kurser har der blandt underviserne været enighed om, at de studerende har vanskeligheder ved at skrive akademiske danske tekster. Således har det været et ønske at styrke de studerendes akademiske skrivefærdigheder. Med støtte fra den sprogstrategiske satsning, som er et femårigt forskningsunderstøttet initiativ (2013-2018), der har til formål at identificere og imødekomme studerendes behov for sproglig støtte på tværs af KU (CIP, 2016), viste dette sig muligt i 2014. Det skete gennem et projekt i samarbejde mellem Center for Internationalisering og Parallelsproglighed (CIP) ved KU og It og Sundhed. I denne artikel beskriver vi projektet, og vi giver konkrete eksempler på formativ feedback fra undervisningen. Afslutningsvis diskuterer vi udbyttet samt udfordringer ved at integrere et eksplicit fokus på fagets sproglige aspekt. 


\section{Kurset i Epidemiologiske metoder}

Omtrent 45 studerende på It og Sundhed følger hvert forår kurset i Epidemiologiske metoder. Formålet med kurset er, at de studerende får kendskab til begreber og designtyper inden for epidemiologien samt, at de bliver i stand til at vurdere epidemiologiske artikler og undersøgelser kritisk. Kurset ligger på uddannelsens 2. semester, hvorfor de studerende endnu ikke er vant til at skrive længere, sammenhængende akademiske tekster. Undervisningen foregår på dansk og består af 13 forelæsninger og 20 holdundervisningstimer, hvor de studerende løser øvelsesopgaver i grupper. Før projektet blev implementeret, blev øvelsesopgaverne gennemgået mundtligt i løbet af holdundervisningen, men de studerende havde ikke mulighed for at aflevere deres opgavebesvarelser og få feedback på dem. Kurset afsluttes med en dansksproget 4-timers skriftlig stedprøve med ekstern censur, hvor de studerende skal besvare spørgsmål om en epidemiologisk artikel. I perioden 2011-2015 var den gennemsnitlige beståelsesprocent i faget 72\% (egen opgørelse).

\section{Overordnet om projektet}

Projektet bygger på to antagelser, og den første er, at fag og sprog, forstået som faglighed og formidlingskompetencer, ikke kan adskilles (Magnusson, 2008; Krogh, 2010; Laursen, 2013). Den anden antagelse er, at den sproglige bevidsthed inden for fagets kontekst er et fælles ansvar mellem underviser og studerende, dvs. at både underviser og studerende forstår vigtigheden af klar faglig formidling (Laursen, 2013). Derudover bygger projektet på fagundervisernes erfaringer med de studerendes skrivefærdigheder, på sprogkonsulentens vurdering af tidligere studerendes skriftlige eksamensbesvarelser og observation af undervisningen på kurset.

Projektet var opdelt i to delprojekter, som begge bestod af 5 timers ekstra undervisning. Delprojekt 1 blev udviklet og gennemført i foråret 2014, hvorefter det blev videreudviklet og gennemført som delprojekt 2 i foråret 2015. Selve forløbet i de to delprojekter strakte sig over henholdsvis 6 og 7 uger. De 5 timers undervisning blev varetaget af sprogkonsulenten og fagunderviseren i fællesskab. Med projektet blev der indlejret et sprogligt mål i et fag, hvis hovedområde ikke er sprog. Vi betragter fagdiskursen, dvs. den måde man taler på og om epidemiologien, som et nyt sprog, de studerende skal lære. Ud fra denne betragtning anskuer vi dette projekt som content and language integrated learning (CLIL) (Coyle et al., 2010), hvor de studerende gerne skulle lære de epidemiologiske metoder og begreber at kende samt lære, hvordan de formidler denne viden på en klar måde over for andre.

\section{Delprojekt 1}

Delprojekt 1 havde titlen Stcerkere akademisk dansk, og det bestod af en indledende forelæsning om akademisk dansk med det formål at gøre de studerende opmærksomme på det sproglige aspekt af deres fag og at få dem til at reflektere over sprogets betydning inden for fagets kontekst. Efterfølgende blev de studerende bedt om 
at udarbejde en individuel skriftlig besvarelse af en øvelsesopgave, hvor de skulle forholde sig kritisk til og besvare spørgsmål om en epidemiologisk artikel, der handler om sammenhængen mellem mobiltelefoni og udvikling af kræft. De studerende begyndte at lave deres besvarelse i en øvelsestime og fik mulighed for at arbejde videre med den på en skriveworkshop, hvor de kunne stille sprogkonsulenten og fagunderviseren spørgsmål til opgaven. Aflevering af besvarelsen var frivillig. Da de studerende havde afleveret deres besvarelser, holdt sprogkonsulenten og fagunderviseren sammen en feedbacksession, som bl.a. inkluderede generelle kommentarer til de studerendes besvarelser. Nedenfor gives nogle eksempler på generelle fagspecifikke kommentarer fra dias vist i feedbacksessionen:

- Nævn og sæt begreberne i spil fx. biologisk interaktion, informationsbias, confounding og selektionsbias.

- Argumentér for, hvorfor det er en svaghed, at fx undersøgelsen er lille, at der er brugt spørgeskemaer, hvorfor grupperne er ombyttelige, hvorfor deltagerne overvurderer deres mobiltelefonbrug osv.

- Udelad irrelevante argumenter fx karakteristika ved andre designtyper, medmindre I bliver spurgt til det.

Kommentarerne herover viser, at den fælles generelle feedback bl.a. lagde vægt på anvendelse af fagtermerne, kritisk læsning af artiklen og argumentation. Feedbacken er formativ, da den både kommenterer de afleverede besvarelser og informerer de studerende om, hvad de skal være opmærksomme på fremadrettet ved at give konkrete råd om, hvad de skal inkludere, og hvad de skal udelade. Ud over den fælles feedback modtog den enkelte studerende desuden individuel, skriftlig fagspecifik og sproglig feedback på sin besvarelse. Nedenfor gives et eksempel på feedback fra henholdsvis fagunderviseren og sprogkonsulenten på en studerendes besvarelse af et spørgsmål fra delprojekt 2 , da det illustrerer typen af kommentarer, de studerende fik. Artiklen til denne opgave handler om sammenhængen mellem børnepasning uden for hjemmet og infektioner. De studerende, der afleverede de skriftlige opgaver, benævnes respondenter, og de har alle fået tildelt et tilfældigt nummer, fx R11. Tallene i parentes markerer undervisernes kommentarer til den pågældende sætning i R11's besvarelse.

Spørgsmål: "Er der overensstemmelse mellem det, du ser i grafen og det overordnede IRR (Incidens Rate Ratioen)?"

R11's besvarelse: "Det er ikke umiddelbart ingen sammenhoengen (1), da den overordnede IRR fortoeller os at der er mere end 5\% større risiko for infektion ved når tilfaeldet er at børn bliver passet ude (2). Men tvartimod fortoller vores graf os at de som bliver passet hjemme er tilfoeldene med ARI meget hyppigere (3)." 
Fagunderviserens kommentarer:

(1a): Hvad betyder sætningen?

(2a): Uklart formuleret

(3a): Kun blandt de yngste
Sprogkonsulentens kommentarer:

(1b) Denne sætning er uklar, fordi der er to negationer (ikke og ingen).

(2b) Gør sætningen mere klar, fx ved at skrive "i de tilfælde hvor børnene passes ude end de tilfælde, hvor de passes hjemme"

(3b) Skriv hellere: "at hos dem der passes hjemme er ..."

Kommentarerne herover viser, at vi både har forholdt os til uklarheder i de studerendes forståelse af den artikel, de har læst, og til deres sproglige formuleringer. Ofte hænger disse to sider sammen, da forståelsesproblemer ofte kommer til udtryk gennem uklare formuleringer, hvilket vi bl.a. talte om i den fælles feedback på deres besvarelser. Vi har forsøgt at give kommentarer, der skal gøre de studerende opmærksomme på, hvorfor og hvordan dele af det, de har skrevet, kan blive mere klare eller korrekte. Ud over kommentarerne der stod direkte i besvarelserne, havde sprogkonsulenten udformet et feedbackskema med overordnet feedback på den enkeltes besvarelse, kommentarer til bl.a. struktur og indhold og anbefalinger til, hvad den studerende skulle arbejde med fremadrettet. Vores fokus på både indhold og formidling understreger projektets CLIL-aspekt, da de studerende ud over at opnå en grundlæggende viden om epidemiologi også lærer, hvordan de skal tale og skrive om epidemiologien.

Da de studerende havde fået fælles feedback og fået udleveret deres egne besvarelser med individuel skriftlig feedback, lavede de en gruppeøvelse med peerfeedback, hvor de skulle give mundtlig konstruktiv feedback på anonymiserede eksempler på andre studerendes besvarelser. Hensigten med denne øvelse var at gøre de studerende mere bevidste om, at de kan lære at skrive bedre opgaver ved både at give og modtage feedback, og hvor vigtig klar formidling af faglig viden er. Vi lagde vægt på, at de studerende skulle være konstruktive, kritiske og kærlige i deres feedback på de andres besvarelser, og på denne måde indgår peerfeedbacken som en del af den formative feedback på kurset. Den formative feedback i projektet dækker dermed over alle de aktiviteter, der kan fremme de studerendes læring.

\section{Evaluering af delprojekt 1}

Efter endt kursus og forud for eksamen blev de studerende bedt om at evaluere projektet, såvel mundtligt som skriftligt. Overordnet var den mundtlige tilbagemelding på delprojekt 1, at de studerende var glade for projektet, men mange syntes, at forelæsningen om akademisk dansk var for generel. Derudover ville de foretrække, at afleveringen blev gjort obligatorisk, og de ønskede, at afleveringen kunne ligge på et 
andet tidspunkt, som ikke faldt sammen med afleveringer i andre kurser. Nedenfor ses to eksempler fra den skriftlige evaluering:

"Jeg deltog ved første sprogkursus, hvor jeg fandt udbyttet minimalt. Undervisningen var meget generel og indeholdt intet nyt for mig. Jeg skal dog ikke udtale mig om, hvorvidt andre på kurset fandt den sproglige undervisning brugbar" (R1).

"Det var fint nok at have den der workshop, men i en eksamenssituation vil jeg ikke toenke over det. Der vil jeg bare koncentrere mig om at få skrevet noget fornuftigt ned og så kommer sprog/ordvalg i anden rokke" (R2).

Kommentaren fra R1 viser, at vedkommende betragter forelæsningen i delprojekt 1 som et sprogkursus, hvilket ikke var hensigten fra vores side. R2 skelner mellem sprog/ordvalg og det at skrive noget fornuftigt ned. Ud fra den antagelse, at sprog og fag hænger tæt sammen, og at faglig viden alt andet lige formidles gennem sproget, er det uklart, hvad R2 lægger i sin skelnen. Disse og andre kommentarer gjorde det klart for os, at vi var nødt til at være mere præcise i forhold til italesættelsen af projektet, end vi havde været hidtil.

I den skriftlige evaluering vurderede de studerende udbyttet af projektets delelementer målt på en skala fra 1 (intet udbytte) til 7 (stort udbytte). Gennemsnitscoren varierede omkring 4,5. Fremmødet til skriveworkshoppen var meget lille, og kun seks studerende afleverede deres besvarelse.

\section{Udvikling af delprojekt 2}

På baggrund af de studerendes og vores egen evaluering af delprojekt 1 valgte vi i delprojekt 2 i 2015 at fjerne både den indledende forelæsning om akademisk dansk og skriveworkshoppen. Derudover tilføjede vi en ekstra afleveringsopgave og en yderligere feedbacksession. De studerende modtog også en skriftlig skrivevejledning udarbejdet af sprogkonsulenten. Skrivevejledningen blev udarbejdet som en del af projektet, og den indeholdt links til hjemmesider med sproglig hjælp, konkrete eksempler på tidligere studerendes opgavebesvarelser og råd om, hvordan man kan gribe sin opgave an. Det var ikke muligt at nå at gøre afleveringerne obligatoriske inden for tidsfristerne for kursusændringer, men der blev gjort meget ud af at opfordre de studerende til at aflevere deres besvarelser. Ud over de strukturelle ændringer fra delprojekt 1 til 2 ændrede vi også projektets titel fra Stcerkere akademisk dansk til Styrket skriftlighed i kurset Epidemiologiske metoder. Årsagen til denne ændring var, at vi gerne ville udelade betegnelsen akademisk, som for nogle studerende forekom for abstrakt eller irrelevant i forhold til kurset. Det er muligt, at ændringen af titlen og italesættelsen af projektet kan have haft en positiv indvirkning på de studerendes motivation for at møde op til undervisningen og for at engagere sig i projektet ved at aflevere skriveopgaverne og deltage aktivt i feedbackaktiviteterne. 


\section{Evaluering af delprojekt 2}

Med indførelsen af ændringerne fra delprojekt 1 til delprojekt 2 var det undervisernes opfattelse, at engagementet blev betragteligt højere blandt de studerende, hvilket gav sig udslag i, at der blev afleveret henholdsvis 42 og 29 besvarelser af første og anden skriftlige opgave ud af 48 mulige. Også de studerendes evaluering af delprojekt 2 var mere positiv end den første evaluering. Tyve ud af treogtyve respondenter skrev, at projektet i høj grad eller nogen grad havde gjort det mere klart for dem, hvordan de kunne gøre deres opgaver bedre.

Nedenfor ses to kommentarer fra henholdsvis R4 og R18 som svar på et spørgsmål om, hvad de har fået ud af projektet:

"Jeg har fået meget ud af tiltaget Styrket skriftlighed. Jeg har loert hvordan jeg skal formulere mig procist, og hvordan jeg skal besvare de enkelte opgaver, som jeg har afleveret. Alt ved styrket skriftlighed kan jeg bruge til besvarelse af eksamens opgaverne" (R4).

"Rigtig god feedback. Bedste tilbagemelding på studiet indtil nu" (R18).

De to kommentarer understreger det positive udbytte, de studerende har fået af projektet, og særligt kommentaren fra R4 vidner om øget sproglig bevidsthed. Vi spurgte også de studerende om, hvordan det havde været at få feedback på deres sproglige formuleringer. Hertil svarede 19 ud af 23 respondenter, at det havde været godt med individuel feedback på deres skriftlige besvarelse.

"Det har voeret godt at scette mere fokus på det sproglige, da der er en del skriftlige afleveringer og eksaminer. Førhen har fokus kun voeret på "resultaterne" (R21).

"Det har voret godt, for jeg kan typisk godt lave sproglige fejl i mine formuleringer. Når man sidder i grupper og arbejder med opgaverne er det "snakkeformuleringer" og gruppedeltagerne forstår hinanden, men når det skal skrives ned skal der ofte toenkes lidt mere over" (R10).

R21 og R10 oplever det positivt, at vi har sat større fokus på det skriftlige formidlingsaspekt af kurset. Med indførelse af de skriftlige afleveringsopgaver trænes den skriftlige formidling nu også i selve undervisningen og ikke blot til eksamen.

Med hensyn til peerfeedback var respondenterne knap så positive i deres evaluering. Vi spurgte dem om, hvad de havde fået ud af at give feedback på deres medstuderendes besvarelser. Hertil svarede syv respondenter ud af 22, at de ikke fik så meget ud af dette, eller at der blev brugt for lang tid på det. Se eksempel nedenfor. 
"Ikke rigtigt noget. Jeg synes ikke, at man skal bruge tid på at rette andres besvarelser, da jeg ikke føler at det giver personlig indloering. Specielt ikke på en universitetsuddannelse. Iscer ikke når alle ikke gør en indsats, og laver "dumme" fejl, fordi de ikke gider gøre sig umage" (R22).

Tolv respondenter siger dog, at de efter denne øvelse er blevet mere opmærksomme på, hvordan man skriver godt, og på hvad man skal undgå.

\section{Eksamensresultat}

Forud for projektet var det studie- og fagleders såvel som sprogkonsulentens forhåbning, at projektet ville få flere studerende til at klare sig bedre til eksamen. Derfor har vi foretaget en kvantitativ analyse af sandsynligheden for at bestå eksamen fordelt på årgang, hvilket kan give et fingerpeg om det mulige udbytte af projektet. Tabel 1 nedenfor viser antallet af studerende, som henholdsvis bestod og ikke bestod den ordinære skriftlige eksamen i Epidemiologiske metoder fordelt på år. Ligeledes viser Tabel 1 den gennemsnitlige adgangsgivende karakter, som årgangen blev optaget med året forinden. Dette er af betydning, da vi forventer, at højere gennemsnitlig adgangsgivende karakter medfører en større sandsynlighed for at bestå eksamen. Endelig viser Tabel 1 den relative sandsynlighed (OR) for at bestå eksamen med tilhørende 95\% konfidensinterval justeret for forskelle i den adgangsgivende karakter. Således udtrykker OR $(95 \% \mathrm{KI})$ sandsynlighed for at bestå eksamen i et givet år i forhold til sandsynligheden i 2011 renset for effekten af, at de forskellige årgange er blevet optaget med forskelligt karaktergennemsnit.

\begin{tabular}{|l|l|l|l|l|l|}
\hline År & $\begin{array}{l}\text { Bestået } \\
(\mathbf{n})\end{array}$ & $\begin{array}{l}\text { Ikke be- } \\
\text { stået }(\mathbf{n})\end{array}$ & $\begin{array}{l}\text { Beståelse } \\
(\%)\end{array}$ & $\begin{array}{l}\text { Gennemsnitlig } \\
\text { adgangsgivende } \\
\text { karakter }\end{array}$ & $\begin{array}{l}\text { OR (95 \% KI) for } \\
\text { beståelse* }\end{array}$ \\
\hline 2011 & 28 & 11 & 71,8 & 5,6 & 1 (ref.) \\
\hline 2012 & 33 & 13 & 71,7 & 6,5 & $1,00(0,76-1,31)$ \\
\hline 2013 & 28 & 15 & 65,1 & 6,4 & $0,91(0,68-1,22)$ \\
\hline 2014 & 41 & 17 & 70,7 & 6,3 & $0,98(0,76-1,27)$ \\
\hline 2015 & 45 & 12 & 78,9 & 6,8 & $1,10(0,87-1,40)$ \\
\hline
\end{tabular}

Tabel 1. *usteret for den gennemsnitlige adgangsgivende karakter. 
Tabel 1 viser, at andelen af de studerende, som bestod eksamen i perioden 2011 2015 har bevæget sig omkring 70\%. Denne andel var lavere ved eksamen i 2013 $(65,1 \%)$ og højere i 2015 (78,9\%). Når der sammenlignes på tværs af årgangene samt justeres for den gennemsnitlige adgangsgivende karakter, ses det, at den relative andel, som bestod eksamen, var 9\% lavere i $2013(\mathrm{OR}=0,91)$ og 10\% højere i 2015 $(O R=1,10)$ sammenlignet med 2011. Det skal dog bemærkes, at der ikke er statistisk signifikant forskel på andelen, som bestod eksamen i årene 2011-2015. Projektet med øget fokus på de studerendes skrivefærdigheder var som beskrevet en del af undervisningen i 2014 og 2015. Når man sammenligner andelen, som bestod eksamen i årene, hvor projektet ikke var en del af undervisningen (2011-2013) med årene, hvor projektet var en del af undervisningen, var sandsynligheden for at bestå eksamen 4\% højere i sidstnævnte periode (OR=1,04 (95 \% Cl 0,81-1,34)) (data ikke vist). Forskellen mellem perioderne er ikke statistisk signifikant. Denne analyse blev ligeledes justeret for forskelle $\mathrm{i}$ adgangsgivende karakter. Det skal for god ordens skyld nævnes, at de observerede tendenser kan skyldes tilfældigheder eller andre årsager, end det at vi i 2014 og 2015 har haft øget fokus på de studerendes skrivefærdigheder. Foruden at flere studerende kunne bestå eksamen, var forhåbningen, at de studerende ville opleve en styrkelse af deres skriftlighed generelt. Vi er opmærksomme på, at ovenstående analyse ikke giver en fyldestgørende vurdering af projektets effekt, idet vi kun måler på eksamensresultater kort efter forløbet. Disse analyser kunne med fordel have været suppleret med analyser af eksamensresultater $\mathrm{i}$ andre kurser, som ligger senere på uddannelsen, samt interviews med de studerende om fx udbytte, motivation for læring og afsmitning på skriftlighed i andre fag.

\section{Udfordringer ved at fokusere eksplicit på fagets sproglige aspekt}

Undervejs i projektet har vi oplevet en række udfordringer i forhold til at integrere et eksplicit fokus på sprog og feedback i kurset. For det første er italesættelsen af projektet meget vigtig, da mange af de studerende associerer betegnelserne sprog og akademisk dansk med grammatikundervisning og korrekturlæsning. Vores hensigt har været at gøre de studerende bevidste om vigtigheden af klar og præcis formidling af den faglige viden gennem sproget. For at kunne se denne vigtighed er man nødt til at betragte formidlingen bredt, så den rummer alle elementerne i den kommunikative kompetence og ikke blot fokuserer på grammatikken (Lund, 2009). For det andet er det essentielt, at både underviser og studerende er bevidste om, at den sproglige bevidsthed er et fælles ansvar. Underviseren er nødt til at stille klare spørgsmål i opgaveformuleringerne og at fokusere eksplicit på koncis faglig formidling i selve undervisningen. De studerende skal samtidig se relevansen og vigtigheden af at kunne formulere deres faglige viden klart, så deres budskab går klart igennem til de forskellige målgrupper, de skal kommunikere med på studiet og i deres kommende arbejdsliv. For det tredje er det essentielt for et positivt udbytte af et 
projekt som dette, at de studerende tager ansvar for egen læring ved at aflevere de skriftlige opgavebesvarelser og ved at engagere sig i aktivt i feedbackøvelserne.

\section{Afsluttende kommentarer}

De studerendes evalueringer og eksamensresultater vidner om, at formativ feedback i undervisningen kan spille en vigtig rolle i at styrke de studerendes akademiske skriftlighed. I tråd med disse fund er det vores indtryk, at de studerende oplever et større positivt udbytte af projektet, efter vi har foretaget de nævnte ændringer. Indførelsen af de skriftlige opgaver skaber øget alignment dvs. en bedre sammenhæng mellem undervisningen på kurset og eksamensformen, hvilket de studerende er glade for. Italesættelsen af projektet spiller en stor rolle i forhold til at gøre de studerende opmærksomme på vigtigheden af klar og præcis formidling af det faglige indhold. De studerende skal gerne kunne se, at fag og sprog ikke kan skilles ad, og at formidlingen af det faglige stof ikke er sekundær. Et projekt som dette ville ikke være muligt uden tæt samarbejde mellem fagunderviseren og sprogkonsulenten, da begge parters viden er nødvendig. Det er vigtigt at bemærke, at projektet har været støttet af studienævn og studieleder og af den sprogstrategiske satsning, hvilket har muliggjort at gennemføre dette tværdisciplinære projekt. Den næste udfordring er at få indlejret projektet som en fast del af kurset. En af overvejelserne i denne forbindelse går på, hvorvidt man fortsat skal have to undervisere tilknyttet forløbet, eller om man kan kvalificere fagundervisere på et universitetsniveau til i højere grad også at fokusere på formidlingen af den faglige viden gennem sproglig feedback. På længere sigt vil det være ideelt at fagunderviseren selv skaber et mere eksplicit fokus på fagets formidling og på sproglig feedback. Vi mener grundlæggende, at det er en god idé, at de studerende får formativ feedback på skriftlige afleveringer undervejs i et kursusforløb, særligt hvis kurset afsluttes med en skriftlig eksamen. Vores observationer og de diskussioner, der er gået forud for dette projekt, peger på, at det fremadrettet vil være nødvendigt at fokusere eksplicit på de studerendes sproglige færdigheder som en del af deres akademiske kompetence, med vægt på evnen til at kunne formidle faglig viden klart og velargumenteret.

\section{Taksigelse}

Vi vil gerne sige tak til den sprogstrategiske satsning, som har støttet projektet.

Katja Årosin Laursen er akademisk sprogkonsulent ved Center for Internationalisering og Parallelsproglighed (CIP), KU. Hun er uddannet cand.mag. i dansk med speciale i dansk som andetsprog. Hun har siden 2012 voeret ansat på CIP og arbejder primoert med udvikling og undervisning af kurser i akademisk dansk for studerende med saerligt fokus på skriftlighed. Derudover rådgiver hun undervisere om sproglig feedback og underviser desuden studerende og ansatte ved KU i dansk som andetsprog. 
Lars Kayser er uddannet speciallaege og ansat som lektor ved Institut for Folkesundhedsvidenskab, KU. LK er studieleder for uddannelsen It og Sundhed og har arbejdet i feltet mellem sundhed og laering bl.a. som leder af det paedagogiske udviklingscenter ved Det Sundhedsvidenskabelige Fakultet i fem år. LK var i perioden 2004-2009 leder af Center for Webbaseret Loering, der i 2006 implementerede e-Ioering ved Københavns Universitet.

Mads Kamper-Jørgensen er epidemiolog med en sœerlig interesse i betydningen af graviditet for kvinders helbred. Mads er ansat som lektor og underviser i epidemiologiske og statistiske fag ved uddannelserne i Folkesundhedsvidenskab, It og Sundhed og Medicin ved Københavns Universitet. Mads er desuden studieleder for uddannelsen i Folkesundhedsvidenskab ved Københavns Universitet.

\section{Litteratur}

Black, P. \& Wiliam, D. (1998). Assessment and classroom learning, i Assessment in Education: Principles, Policy \& Practice, 5(1), 7-74, DOI:

10.1080/0969595980050102

CIP (2016). http://cip.ku.dk/satsningsomraader/sprogstrategisk-satsning/ Coyle, D., Hood, P. \& Marsh, D. (2010). CLIL - Content and Language Integrated Learning. Cambridge: Cambridge University Press.

Krogh, E. (red.) (2010). Videnskabsretorik og skrivedidaktik. Rapport om et forsknings- og udviklingsprojekt med deltagelse af Avedøre Gymnasium, Kongsholm Gymnasium \& HF samt Syddansk Universitet. Gymnasiepcedagogik, nr. 77. Odense: Syddansk Universitet .

Laursen, Katja Årosin (2013). Det er sprogligt - selv hvor du ikke loegger maerke til det en empirisk undersøgelse af sproglige og faglige vanskeligheder hos farmaceutstuderende med dansk som andetsprog på Københavns Universitet, Københavnerstudier i Tosprogethed Studier i Parallelsproglighed, Bind C4, Københavns Universitet, Det Humanistiske Fakultet.

Lund, K. (2009). Fokus på sprog. I M. Byram, A. S. Gregersen, B. Henriksen, A. Holmen, K. Lund, M. Olsen \& L. S Stæhr: Sprogfag i forandring. Paedagogik og praksis. Frederiksberg: Forlaget Samfundslitteratur, 85-126.

Magnusson, U., (2008). Språk i ämnet. Intern rapport fra Institutionen för svenska språket. Göteborg: Göteborgs Universitet. 